\title{
Joint Responsibility at its Peak - Searching for a New Nordic Unemployment Model
}

1 Tora Dahl'

Ph.D., Karlstad University, Sweden

\begin{abstract}
Earlier research has shown that the Nordic Ghent' systems seem to be weakened. The unemployment insurances administered by the unions have experienced a decline in numbers of members, very similar to the drop in trade union membership. This article takes its point of departure in previous research into the decline in the membership densities of unemployment insurances in several Nordic countries. The article examines these tendencies and focuses on a new and rather atypical example of organizing unemployment systems in a Nordic context, namely that of the Faroe Islands. Based on interviews and documentation analysis, the article describes the system extensively and argues conclusively that the Faroese unemployment insurance system is an example of the deeply rooted Nordic negotiation tradition, albeit in a new context in which the labor market parties stand united to ensure the system's autonomy from political influence.
\end{abstract}

\section{KEY WORDS}

Ghent system / labor market stability / negotiation traditions / political influence / unemployment insurance systems / union density.

\section{Introduction}

n the Nordic labor market model, the unions play an important role. Recent research has shown that the position of the unions in the Nordic Ghent countries has weakened (Böckerman \& Uusitalo 2006, Kjellberg 2006, Lind 2007). In the Ghent countries, unemployment insurances are closely linked to unionism and have thus affected a high union density (Frege 2006, Kjellberg 2011). A consequence of the trend in the Ghent countries is that an increasing proportion of the labor force is either without economic protection or has a very low degree of it vis-à-vis unemployment. This provides movements that advocate the implementation of obligatory unemployment insurance with arguments. Such a scenario could weaken the union's position further since the traditional link between economic security and unionism would disappear (Andersson et al. 2006). Consequently, this would also weaken the Nordic labor market model in which a low degree of labor market regulation is compensated for by collective agreements resulting from negotiations between the labor market representatives. In fact the legitimacy of such a self-regulatory system could be questioned should union membership densities reach a critically low level. Another conceivable effect of the decline in

\footnotetext{
${ }^{1}$ Tora Dahl, Ph.D., Department of Work Life Science, Karlstad University, Sweden.

E-mail: tora.dahl@kau.se
} 
unemployment insurance membership is linked to the notion of de-commodification, i.e., the extent to which the individuals of a given society are guaranteed a reasonable livelihood in case they become, for example, unemployed (Esping-Andersen 1990). It is plausible that uninsured employees will lower their minimum demands regarding employment conditions should they become unemployed, thus undermining the general labor force in terms of working conditions. Finally, another imaginable consequence of this decline is that responsibility for the individual's economic well-being is signed over to a third party. Under the Nordic welfare model, this would be the state.

The public debate on unemployment insurance systems has, however, largely focused on whether or not paid membership should be mandatory, and thus not so much on how a potential unemployment insurance system should be structured. As such, discussion about the future of the Nordic unemployment insurance systems has been rather narrow. By looking at a relatively new example of a Nordic unemployment benefit system (UBS), which has thus far not been described, this article seeks to exemplify how a mandatory UBS could arise. An interesting aspect of this system is that it includes the element of compulsory payment while at the same time enhancing the influence of the labor market parties. Thus, the labor market parties seek agreement and take joint responsibility for the unemployment system; as such, it is an example of the long-standing Nordic negotiation tradition, but in a new context.

In contrast to the majority of the Nordic societies, the Faroe Islands chose to organize its unemployment system on the basis of obligatory membership when establishing it in 1992. ${ }^{2}$ Despite the system's obligatory membership, the unions have not experienced a notable decline in membership levels since it was launched. Perhaps, this has to do with the fact that the system is to some extent structured in accordance with the principle of the Ghent system. Paid unemployment membership is compulsory for employees and employers and is raised like taxation, similar to many other European countries. At the same time, unemployment insurance is integrated with job centers. Finally, this is all administered by a board consisting of labor market representatives. As such, the Faroese unemployment system is unique. In light of recent developments in the other Nordic countries, it is interesting to see how the system is structured, as well as to what extent the labor market representatives actually have any influence.

\section{Objectives and research questions}

The aim of this article is to shed light on the relatively new Nordic UBS used in the Faroe Islands. This will be done by focusing on the system's origin, structure, importance, strengths, and weaknesses. In relation to this, two main questions are posed, the first of which deals with the issue of how decisions are made and negotiated, while the second concerns the extent to which political influence is visible within the system. Empirically, the article draws on interviews with respondents who are directly or indirectly involved in the development and/or administration of the Faroese unemployment system. In addition to this, the findings presented in the article are based upon the analysis of various documents describing the unemployment system, as well as upon prior research.

The article is structured as follows. First, a brief overview of the method of data collection and analysis is given. After this, the article is contextualized by giving a short introduction to the Nordic setting, followed by a short presentation of some relevant 
facts regarding unemployment on the Faroe Islands. Finally, empirical analysis is presented, followed by a concluding section.

\section{Methods and materials}

The findings presented in this article are based upon 10 qualitative expert interviews documented during the summer and early autumn of 2011. In addition to this, the findings are also supported upon the documentation analysis of policy documents, reports, and legislative documents dealing with the Faroese UBS. In order to bring breadth to the responses, the selection of respondents is based upon the principle of achieving an even level of representation among the different parties involved in both decision-making and the implementation of decisions. This resulted in a selection consisting of board members, administrative staff, and politicians. The interviews with the politicians were conducted partly in order to fill in data regarding the origin of the system, but also to see to what extent they felt they were exerting any influence on the direction of the board's decisions. As regards the interviews with the board members, these were conducted in order to understand how the decision-making process functions within the board and to understand how the board members view their own role. The aim was to obtain an even level of representation between employees or trade union representatives, on the one hand, and the employers' association, on the other. In this selection, I have also made sure that both the public and private sectors are represented. Some of the respondents were pioneers when the system was established and were thus able to supply information about its origin. Others were relatively new in their positions. In order to understand how decisions are implemented by the administration and board, some interviews were conducted with administrative staff. These were also meant to provide an understanding of how the integration of unemployment insurance payments and job centers works.

\section{A Nordic outlook}

Today, most welfare states have some sort of unemployment insurance or benefits system. ${ }^{3}$ The first of its kind was established in 1892 in the United Kingdom and financed purely by membership fees. Although a typical way of structuring the original unemployment funds, this changed in 1901 when the first publicly subsidized, but still union-administered, unemployment fund was introduced in the town of Ghent in Belgium (Holmlund 1998). The Ghent system, as a means of organizing and financing unemployment funds, then spread to other European countries, albeit in most cases for a very limited period of time. After World War II, compulsory unemployment insurance replaced the former Ghent system in most countries (Clasen \& Viebrock 2008, Holmlund 1998).

In the Nordic context, however, the Ghent system has survived. At least, that is the case for Sweden, Denmark, Finland, and Iceland. Historically, the Nordic Ghent system is closely linked to unionism and, traditionally, unions have held, and still hold, a firm position in the Nordic labor market. The close connection with unions means that the unemployment insurances of the Ghent system have been sector-specific, i.e., members of a union have often been members of the same or equivalent unemployment insurances, thus reflecting labor market segregation. The outcome of this is that the 
social segregation that exists within, for example, the Swedish trade union system has also been reflected within the Ghent system, resulting in divergent fund contributions depending on which funds employees belong to (Kjellberg 2009:1). Another effect of the Ghent system is that the unemployment insurance structure has grown from underneath and up from small-scale insurance to more of a general, but voluntary, welfare insurance system at its peak. This is in contrast to how other welfare institutions are structured; in fact, much earlier research has linked the unions' high membership rates to the unionadministered unemployment insurances of the Ghent system (Lind 2007, Scruggs 2002). However, recent research has also shown that the Ghent system seems to be under pressure. In parallel with the decline in union membership, the unemployment insurance funds have also experienced a drop in membership. In the Swedish case, this trend of giving up unemployment insurance is so prevalent that it has been categorized as a mass exodus (Kjellberg 2009:2). A similar situation is reported from Finland by Böckerman and Uusitalo (2006). Perhaps the most alarming news about the decline in unemployment insurance membership is that it is not borne equally by all the groups on the labor market, meaning that some groups have given up their insurance at a higher rate than others; unfortunately, these are the groups largely running a higher than average risk of becoming unemployed (Kjellberg 2010a,b).

This trend is not, however, an isolated problem for the Ghent countries. In a comparative outlook, covering 20 European countries, on the issue of social partners and the social security systems of Europe, the authors find a clear shift in how unemployment benefit is viewed from "protection to activation," as they conclude. They also note that the role of the social partners has weakened in the majority of the investigated countries (Schaapman \& van het Kaar 2007).

Indeed, in a report presented by the Confederation of Swedish Enterprise, there are calls for a market-adapted alternative to the state-regulated insurance funds that exist today. In fact, one of the concluding questions posed in the report is whether or not the state-regulated system has suppressed potential market-based initiatives. Not surprisingly, perhaps, the report concludes that, in order to arouse interest among insurance companies, regulation of this sector will have to be limited to the bare minimum. In addition, the insurance companies will, of course, need to seek ways of avoiding insuring the "high-risk groups," concludes the report (The Confederation of Swedish Enterprise 2011).

When confronted with the increasing number of employees that have given up their unemployment insurance, one of the formal explanations often given by both the former Danish government and the present Swedish one is that individuals do so of their own free will. Even when attention is called to the fact that the decline is closely linked to different structural changes implemented by means of political influence being brought to bear, politicians claim that the changes have indeed been made in order to enhance the individual's freedom to choose.

\section{Unemployment on the Faroe Islands}

The first time a potential unemployment insurance was discussed on the Faroe Islands was in 1918. At that time, it was suggested as a system for unemployed fishermen. In the 1920s and 1930s, too, there were discussions regarding the need for economic security during unemployment; yet this did not result in any concrete action (The Nordic 
Table I Fluctuations in the unemployment levels between the launch of the UBS and $201 \mathrm{I}$.

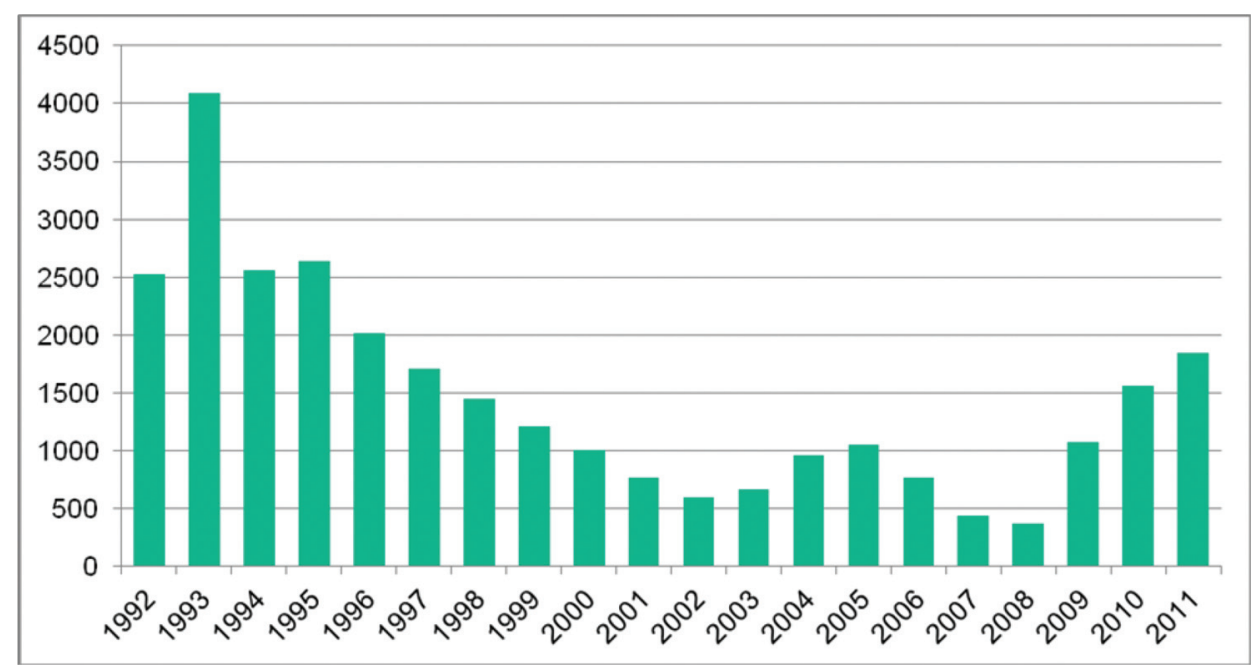

Source: Arge (2011)

Council of Ministers 2011). One problem with the unemployment statistics on the Faroe Islands is that the unemployment figures were not registered systematically before the establishment of the UBS in 1992 (Statistics Faroe Islands 2012). Thus, it has not been possible to create any long-term analysis of the unemployment levels. One can assume, however, that the unemployment levels probably have not been so high since the unemployment system was not established until during the 1990s.

In reported numbers, available from Statistics Faroe Islands, it can be seen that unemployment rates have gradually been dropping, from $12.9 \%$ in 1995 to $1.3 \%$ in 2008. Recently, however, the trend seems to have changed, with the average number of unemployed during 2011 being 6.8\% (Statistics Faroe Islands 2012).

The majority of the female labor force work in the social and service sectors, while men mainly work in production, e.g., the fishing and construction industries (Mýri 2011). Even though female participation in the labor market is relatively high, at $81.4 \%$, compared with the male employment rate, at $85.3 \%$ (Statistics Faroe Islands 2011), statistics show that more than $60 \%$ of the female labor force work part-time as opposed to $19 \%$ of the men (Munch Haagensen 2011).

It is important, in this connection, to be aware of the fact that, since the part-time unemployed are not included as potential recipients of benefits, they are neither registered nor included in the unemployment statistics. Hence, the extent of part-time unemployment on the Faroe Islands is simply a matter of speculation.

\section{How the system works}

The Faroese UBS has multiple tasks. One of these is to share out and decide on payments. Another is to assign jobs and the third is to upgrade the labor force. The unemployment 
system's decision-making body is a board. This board consists of seven members appointed by the Minister of Labor Market Affairs following nomination by the labor market parties. The employees and employers are represented by three members, each elected for a 4-year period. The seventh member is the chairman, appointed by the Minister of Labor Market Affairs, who takes on the role of mediator should the parties encounter difficulties reaching a consensus when making decisions. The constitution of the board is regulated by law, as are the privileges and obligations applied to it (Parliamentary law 113:1997).

The board is tasked with the administrative and financial responsibility for the UBS. This includes the job center unit, as it is integrated into the system. It is also the board that decides on and employs the director of the job center unit. Even though the system has multiple tasks, the board has delegated most of the administration and control of the job center unit to an administrative office. This, as well as any administration of unemployment payments, is entrusted to a division within the job center unit. The board decides on the levels of unemployment payments, albeit within a given framework. The board is also entrusted with determining the budget of the job center unit. Thus, one could say that the system also finances costs, at least to some extent, as well as deciding on the direction of the country's active labor market policy. In the original work proposal handed over to the parliament by the committee in 1992, the system was to be structured as a voluntary insurance scheme for the employees; it would thus only be the employers that had to pay for the obligatory part of the system (ALS 2003).

The system's finances are based upon an obligatory tax drawn directly from the employee's salary and in collaboration with the national taxation office. The same percentage is drawn from the employers for each employee on the payroll, as well as from those who have taken out voluntary insurance, i.e., the self-employed. At the time the interviews were conducted, the contribution amounted to $1 \%$ of salary. The contribution can never exceed $2.5 \%$ without parliamentary approval since this would require changing

Table 2 The percentage level of unemployment contributions and benefits used in the UBS during the period 1993-2012.

\begin{tabular}{ll}
\hline Period & Percentage \\
\hline $2012-01-01-$ present & 1.25 \\
\hline $2004-07-01-201$ I-I2-31 & 1.00 \\
\hline $2003-09-01-2004-06-30$ & 0.75 \\
\hline $2003-01-01-2003-08-3 \mid$ & 0.50 \\
\hline $2001-04-01-2002-12-3 \mid$ & 1.25 \\
\hline $2000-07-01-2001-01-3 \mid$ & 1.50 \\
\hline $2000-01-01-2000-06-30$ & 1.75 \\
\hline $\mid 999-01-01-1999-12-31$ & 2.00 \\
\hline$|998-01-01-1998-12-3|$ & 2.25 \\
\hline$|997-07-01-1997-12-3|$ & 2.50 \\
\hline $\mid 993-04-01-1997-06-03$ & 2.75 \\
\hline
\end{tabular}


the law governing the UBS (Parliamentary law 113:1997). The benefit is based upon the individual's income at the time of becoming unemployed, and retroactively for 12 months. The maximum monthly benefit is $80 \%$ of income up to a maximum of DKK 20,000 per month for a period of 253 days. Once this period has expired, the benefit is lowered to a maximum of DKK 18,750 per month. There is also a limit to the period during which you can receive unemployment benefit, which is 648 days spread over a period of 3 years. After this, the benefit is withdrawn for 24 months (ALS: 2).

The board has been given the mandate to freely regulate payment levels, albeit within a given framework. In 2009, however, parliament decided that the board needed to obtain approval of decisions regarding payment levels by means of a parliamentary majority (Parliamentary law 113:2009). Thus far, however, the political system has never gone against changes proposed by the board.

\section{Findings}

\section{The emergence of the Faroese unemployment system}

The description of how the Faroese unemployment system has evolved takes its point of departure in the greatest economic crisis the country has ever experienced. The distressing situation in the early 1990s required collaboration between the labor market parties. The tendencies were clear; an economic crisis was on its way and with it, consequently, rising unemployment. The Minister of Labor Market Affairs appointed a committee, consisting of labor market representatives, to draft a proposal for an unemployment system. Not surprisingly, the committee presented a proposal in which the labor market representatives would control the unemployment system but in which the payments entering the system would be in the form of a mandatory tax. To a large extent, this initial structure has remained intact.

"It was a real turbulent beginning because of the economic storm. [...] and from a constitutional perspective the Unemployment Insurance System actually is a bastard."

During the committee's initial phase, there were discussions about whether the unemployment system was to be voluntary or not. However, since the risk of unemployment was unevenly distributed between the employees on the labor market, the committee concluded that voluntary insurance would weaken the system since those at low risk of becoming unemployed would choose to stay outside it. One of the respondents described this as historical, but emphasized at the same time that this compromise worn a lot on the committee members. Thus, the final suggestion was for obligatory unemployment insurance integrated with job centers and administered and controlled by a board with representatives from both sides of the labor market. The interviews also showed that the union membership density had remained around $80-90 \%$ and that no significant decline was reported after the implementation of the UBS. There is also a relatively high degree of union density, about 50 registered, meaning that it is easier to maintain a close relationship with the members. ${ }^{4}$

Initially, the system was heavily criticized in the public debate and, to some extent, even by politicians. The respondents said that there was a rather widespread mindset 
among the public that was based on a sense of humiliation over being unable to support themselves. Thus, having a system in which you would get paid for doing nothing was not entirely acceptable.

"The general notion was that this [the unemployment system, author's remark] was not necessary. The fact that you would have a system where people would get paid to do nothing was considered rather strange."

The respondents, who were active in 1992 when the system was launched, stated that, even though there were voices advocating an unemployment system as such, the general view was that it was unnecessary. In addition to the reasons referred to in the citation above, opposing opinions were also based upon public dissatisfaction with the fall in general welfare levels that had been one of many consequences of the economic crisis. Obligatory unemployment benefits would mean additional taxation; initially, the level of payment, $2.75 \%$, into the unemployment system was considered rather high. Conclusively, the initial phase was described in terms of resistance and, perhaps, in terms of being a contributory factor to why the politicians had chosen to delegate the responsibility to the labor market parties.

In March 1992, the first payments entered the system, and in August of the same year, the first unemployment benefits were paid out. Due to the large rate of unemployment, the fund had difficulties raising enough money to make its initial payments. Some of the respondents mentioned the lack of commitment on the part of the politicians who, after the establishment of the unemployment system, more or less turned their backs.

"[...] as soon as the system initiated the politicians laid their heads on a pillow: Fine, now the labor market parties will solve this matter."

Due to the lack of a financial buffer, the initial phase was characterized by insufficient capital to meet unemployment payments. Over time, however, this shortfall has turned into a financial surplus, and around the time when the interviews were being conducted, the fund had roughly DKK $600 \mathrm{~m}$ in its coffers.

\section{The necessity for a public unemployment system}

The Faroese UBS being obligatory, instead of voluntary, as is the case in many neighboring Nordic countries, can be seen as rather odd. Arguments concerning the necessity for compulsoriness, in terms of payments, include a voluntary system being both more expensive and weak due to membership catchment being limited to groups at high risk of becoming unemployed.

However, the point has also been made that the unemployment system stabilizes the economy on multiple levels. Firstly on a national level, as the economy is not so easily affected by fluctuations. The system ensures that the "wheels keep on turning," as one of the respondents expressed it. Secondly, the system stabilizes the individual's personal finances, enabling him/her to maintain a somewhat stable position even when unemployed. This provides a sense of reassurance on the individual level, but it also 
safeguards the individual's financial credibility vis-à-vis institutions, i.e., banks, etc. Finally, in the respondent's perspective, the system makes it more probable that the labor force will remain in the country and, hence, available for the labor market when needed. Whenever this argument is put forward, the respondents are often reminded of the consequences of the economic crisis of 1992 when the country experienced mass emigration.

"Many fled the country because of the economic crisis and this is something still visible today in the population-loss from a specific period. It's not enough to have financial growth, you also need population growth.”

Thus, the system provides the labor market with a kind of labor force reserve, and in order to encourage that labor force to remain, during less prosperous times too, unemployment benefits function both as a financial motivation factor and as a financial safety net. The respondents are of the view that a security system like this will ensure that the labor force is more easily obligated to ride out the storm, so to speak, and, in that sense, the system will stabilize emigration levels.

\section{Without political influence ... or interference}

Another positive aspect of how the system that the respondents refer to works is the system's simplicity and flexibility, which facilitate decision-making. The fact that the Arbeiðsloysisskipanin (The Faroese unemployment system, ALS) is a public unemployment system which, in spite of that, lacks any direct political influence is mostly viewed as strength; however, from time to time, the weaknesses of this kind of structure are also noted.

\footnotetext{
"But no, the politicians are not alert. They [the politicians, author's remark] are content as long as they don't hear anything. But you know how it is: the weakest groups cannot stand up for themselves; they aren't fit for fight because they are fully occupied with survival."
}

In this connection, some board members also emphasize the importance of adopting a solidarity-based style of thinking, and not just seeing the interests of the members they represent.

The system's independence from the national economic plan is seen as both strength and a necessity. The lack of any political influence strengthens the system in the sense that the fund's financial resources are not affected by variations in the political landscape, thus allowing the board to make long-term plans and investments. The necessity of having the system in its present structure relates to the concerns the board members express as regards what would happen to the fund's financial availability if it were to be controlled by politicians. The board members suspect that an imbalance in the benefit levels paid to the unemployed and a drained financial buffer would be a conceivable scenario. In their view, a conceivable consequence of having the unemployment system under political administration would be the jeopardizing of the financial stability of the 
individual in particular, and of the system in general. Suspicions like these are based upon previous experience:

"Especially in prosperous times of [financial, author's remark] growth, there was a persistent badger from the politicians that unemployment insurance should finance different areas such as education etc. There have been lots of fights."

And, according to the respondents, there have been several so-called self-invites on the part of politicians to use the fund's considerable financial resources for various societal useful projects. But one point of concern mentioned is that somewhere along the line, overall national labor market policy has vanished. Parallel to, or perhaps as a consequence of, the fact that the labor market representatives have assumed the responsibility for the most pressing labor market matters, other issues, e.g., the long-term analysis of future labor market needs and the strategies for meeting these needs, have been neglected, in their view, by the politicians. This critique is made at the same time as the board members, in particular, are eager to point out the advantages of a system that is free from political influence.

"[...] the board members will not support a suggestion that could result in a decline in their own membership numbers. And as such, you may have a point in that shouldn't you have some, at least advisory organ... but the strange thing about the board is that every time some political interference has been suggested, the parties get together and say: Hell no, it's one thing that we don't agree but those villains are not to get access."

Thus, the interviews also indicate that long-term labor market investment having been neglected is, in fact, connected with the way in which the system is constituted. The discussion about who should have the responsibility for overall labor market affairs becomes somewhat unclear.

Even though the unemployment system is funded via taxation, a rather obvious sense of ownership of it is visible among the board members. This may partly stem from the fact that the labor market representatives have been involved in working on the system from the establishment phase onward; however, most of these have now been replaced. Another argument for the labor market parties having sovereignty over deciding about the fund's assets is the simple fact that it is the labor market parties that finance the system:

"We [the board members, author's remark] have seen eye-to-eye about the fact that the unemployment insurance should not be in the national economic plan. And it's a reasonable demand since it's the labor market parties that pay every penny into the system."

Another result of the structure of the board is that decisions are made in a spirit of consensus, in turn linking the labor market parties more closely together. According to the interviews, this has strengthened both the ties and the cooperation between the labor market parties, even though they disagree on a lot of matters:

“[...] you compromise and what you get is rarely ideal but perhaps it's good enough. It's not logic, science, or even what's always the best-it's what you've succeeded in agreeing upon. That's perhaps the flipside of the coin." 
Consequently, you cannot expect to agree upon everything; you have to negotiate and be satisfied with the result. Another strength of the system is its simple structure, which also makes things easier when decisions are to be taken. The board members' general view is that, if decisions were to be made through a political procedure, this would be a much more time-consuming procedure that would delay the executive process.

\section{Exposed or simply lazy?}

"In the Faroe Islands, we have one system—a simple system that actually works equally for all."

As stated above, the simplicity of the system guarantees that all are treated equally. But when discussing this matter further, it is, in fact, the lack of variation or of any special conditions and considerations within the system that results in some individuals or groups experiencing difficulties. Since both work and personal conditions vary extensively between employees, this lack of differentiation becomes a problem for those who do not match the norm, so to speak. While administering a simple system may indeed be uncomplicated, this simplicity may instead act as a threshold that is impossible for those not matching the norm to cross.

Defining unemployment is also problematic. As the system works today, you have to have been given notice before getting any benefits. This is complicated both for those who are self-employed and for those who are partly unemployed, or who are seasonally unemployed or who only have part-time employment. The fact that it is not possible to register as part-time unemployed also affects some groups more than others.

"It's only women who encounter this misfortune [...] and its discrimination against women."

As the system works today, it is not possible to be part-time unemployed; effectively, you cannot receive part-time unemployment benefit. The reason for this rule is largely to be found in the fact that more than $50 \%$ of the female workforce has part-time employment; thus, according to the respondents, a system offering part-time unemployment benefit would be impossible to administer.

"[...] the problem is that you'll have some who abuse this. Then somebody might say: Why should I work full-time when I can work part-time and get the other half from the ALS? Not that you should be suspicious of people, but it's an underlying part of this type of welfare system that it will always be exposed to a certain amount of abuse, people are creative."

Hence, changing the system to make it possible to be part-time unemployed would make it easy for the female workforce to cheat, claiming that they were part-time unemployed when, in reality, they never had the aim of working full-time in the first place. This latter issue was expressed as a suspicion directed at the female workforce.

Another suspicion concerns the ongoing debate and the challenge for the board to balance levels of unemployment benefit. At the time the interviews were conducted, the monthly level of benefits was $80 \%$ of income, or a maximum of DKK 20,000 per 
month. ${ }^{5}$ However, due to indications regarding employees resigning from their jobs in order to live on unemployment benefits, the majority of the respondents viewed this level as too generous. In particular, suspicions of cheating were directed at recipients such as the nearly retired and the very young. In the long-term perspective, the respondents saw risks that this form of voluntary unemployment could become a sanctuary for young recipients. Thus, the generous level of unemployment benefit meant that the incentive to be gainfully employed became less relevant, something that was particularly visible among the above-mentioned groups.

"There are lots of big discussions that ... actually are political such but that the politicians don't really face up to. It's a bit like the political system is afraid to challenge the board when it comes to this."

At the same time, the benefit levels have to be sufficient in the sense that people are able to maintain a reasonable standard of living while unemployed. The reasons for the relatively high levels of unemployment insurance benefit largely concerned the fact that the fund, due to a low rate of unemployment, was able to afford to make generous payments and was thus not so much a key discussion about what a reasonable level is. But the flipside, however, seemed to be that some employees abuse this and actively choose unemployment. The generous levels of unemployment benefit also give rise to suspicions about cheating. These suspicions were mainly based on rumors that had come to people's attention and thus if and to what extent this was actually a problem was hard to define. Groups that were the victim of this type of suspicion were mainly youngsters on low pay, but those close to retirement are also mentioned as a potential group within the workforce which, through the ALS, has the opportunity to take early retirement: both the unemployed who have good financial circumstances and employees who are burnt out.

\section{Limitations to the assignment and the consequences of this}

The interviews also implicate an ambivalent attitude to the limits of the board's assignments. Given their position as board members, several labor-market-related problems came to their attention. Many of these lay beyond their immediate remit. This, in combination with the complexity of the issues, raised awareness of the limitations to their mandate in parallel with a wish for the issues to be resolved. The board's representatives expressed a lot of ideas and concerns which had come to their attention and which they, in their position as labor market experts of a kind, saw necessary to regulate. At the same time, their assignment was limited to administering and further developing the unemployment system, not regulating labor market affairs that are, in fact, a matter for the government. Thus, the limit between their actual assignment and political such in some regards became indistinct.

But limiting the assignment also entailed some labor market matters being left to their own devices. One example given was the situation for the high numbers of students doing higher education abroad. Due to the requirement of holding employment for a minimum of 6 months before receiving unemployment benefits, students coming directly from university had a hard time safeguarding their financial stability upon returning to the Faroe Islands. 
"If you think about society as a whole, the importance of getting people to return home when they've been studying, then it doesn't make any sense. [...] and if the decision had to be made by the government, then they'd have been very fast to change this rule in order to get the youngsters to return home."

Since the board members represent their members and consequently individuals who either were or have been active on the labor market, benefits for groups such as newly graduated students were not their primary concern. Thus, one consequence of the fact that the labor market parties assume the responsibility for the UBS, as well as other labor market issues, is the government limiting its focus on these matters. Nevertheless, this was seen to be of great importance to society in general, and to the individual in particular, and as such constitutes an example of the discrepancy between the board's actual tasks and those of a general labor market policy.

\section{Conclusion}

This study set out to describe the Faroese UBS in a Nordic retrospective. Due to the system's novelty, the general focus has been on illuminating its origin, structure, and importance to society in general. On a specific level, the focus has been on obtaining an in-depth view of how decisions are made and negotiated, as well as the extent to which political influence is visible within the system. The data are based upon expert interviews with labor market representatives on the board, with administrative staff, and with politicians, as well as upon an analysis of various documents.

The case study presented in this article shows that, in regard to its structure, the Faroese UBS is rather at odds with the systems seen in the neighboring Ghent countries. However, the system is based on the long-standing negotiation tradition and the autonomy of the labor market parties, which characterize the Nordic labor market system, and in this sense there are convergent tendencies as well between the Faroese example and the Ghent system.

Payments into the Faroese UBS are obligatory and the system is self-financed. In this sense, there is a major difference vis-à-vis the Nordic Ghent system. However, as membership of unemployment insurance schemes is falling within the Ghent system, the need to find new ways of developing these is becoming more immediate and often being accompanied by discussions about obligatory state-controlled unemployment systems. In this connection, attention is rarely paid to the fact that obligatory and state-administered unemployment insurance would diminish the union's position, leading to a further fall in union membership density. Indeed, previous research has focused on the fact that union-administered unemployment insurances also function as a recruitment base (Scruggs 2002). However, the findings from the Faroese case study show that unions can maintain their membership levels even after the implementation of a mandatory UBSat least as long as the unions exert some influence on how benefits are distributed.

The findings also indicate that the liberal political view, i.e., that membership in unemployment insurance is a matter for the individual to decide about unemployment, is not represented in the Faroese case study. More exactly obligatory UBS is not discussed as a matter of if but rather how to take and coordinate the joint responsibility for unemployment as phenomena. In the Faroese case, unemployment is seen as something 
constructed by and on the labor market, hence it is a matter for the labor market parties to confront.

An additional conclusion is that the contradictions, between the labor market parties, were not as significant as one could expect; instead, the respondents showed a remarkably unified line in relation to many overall viewpoints. One would think that this type of system would entail implicit difficulties in reaching agreement upon, and deciding about, issues; but my findings show that this is not entirely the case. There is no doubt, however, opposing opinions due to contrasting positions; yet, what unites the labor market parties is the strong view that politicians must stay out of their business.

A major weakness, however, with the Faroese UBS is that part-time unemployment is not included. It would be naive to think that part-time unemployment does not exist in the Faroe Islands, as it does in the other Nordic countries. At the same time though, it is also difficult to confirm the extent of this problem because of the widespread occurrence of part-time employment among the female workforce, in combination with the fact that part-time unemployment is simply not registered.

The structure of the Faroese unemployment system adds to the legitimacy of the role played by the labor market parties within the tri-party system. Even though the initial motives for delegating responsibility for the unemployment system, to the labor market parties, rather seems to have been based upon a political inability in combination with a public mistrust of politicians, rather than a conscious strategy, the result has nevertheless been the strengthening of the labor market parties' position and the further entrenching of their professional relationships. The constant "threat" of political interference helps to strengthen the collaboration between the board members, unifying them and thus facilitating a cooperation that results in consensus-based decisions, even when this means compromising.

As with any other unemployment system, the Faroese one is a product of a long and complex process of historical development that is impossible to describe in detail in one article. The Faroese unemployment system evolved during times of economic instability and high unemployment, as was the case in the neighboring Nordic countries. The difference, however, in the Faroese case study lies in the fact that the need for an unemployment system did not become urgent until several decades later. Therefore, the system was launched once the negotiation tradition between the labor market parties had been profoundly established; hence, the prerequisite of the labor market parties maintaining and administering a system was already in place. Although the labor market parties were often in an opposing position, they were also skilled negotiators. In addition to this, the political landscape was unstable, with a low degree of trust in political representation, something which forced the labor market parties to somehow act in unison. This has later developed into an approach, a body of language you might say, that is applied by the board members as a way of achieving consensus during the process of decisionmaking, while simultaneously keeping the system free from political influence. In this sense, it has developed into a strategic instrument.

In the search for a new Nordic unemployment model, this article set out to focus attention on a different way of organizing an UBS. Quite unlike the falling membership levels of both the unions and of the unemployment insurance schemes administered by them, as seen in the other Nordic Ghent countries, the Faroese case study rather implies that the influence which the labor market parties have been given, through the unemployment system, has further empowered these organizations' positions, and maybe even the members they represent as well. The question is, however, for how long. 


\section{References}

Andersson, D., Lindblad, J. \& Löfgren, A. K. (2006) Gemensam Arbetslöshetsförsäkring? LO-rapport, LO Stockholm.

Arge, U. (2011) ALS 20 ár-Frá útgjaldsskipan til kraftdepil. ALS, Tórshavn.

Böckerman, P. \& Uusitalo, R. (2006) Erosion of the Ghent System and Union Membership Decline: Lessons from Finland. British Journal of Industrial Relations 44: 2.

Clasen, J. \& Viebrock, E. (2008) Voluntary Unemployment Insurance and Trade Union Membership: Investigating the Connections in Denmark and Sweden. Journal of Social Policy 37, 3: 433-451.

Esping-Andersen, G. (1990) The three Worlds of Welfare Capitalism. Princeton University Press, Princeton, NJ.

Frege, C. (2006) International trends in unionization in Morley, M. J., Gunnigle, P. \& Collings, D. G. (eds.) Global Industrial Relations. Routledge, New York, NY: 221-238.

Holmlund, B. (1998) Unemployment Insurance in Theory and Practice. Scandinavian Journal of Economics 100, 1: 113-141.

Kjellberg, A. (2006) The Swedish Unemployment Insurance-Will the Ghent System Survive? Transfer, European Review of Labor and Research 12: 87.

Kjellberg, A. (2009:1) The Swedish Ghent System and Trade Unions under Pressure. Transfer, European Review of Labor and Research 15: 481.

Kjellberg, A. (2009:2) Det fackliga medlemsraset I Sverige under 2007 och 2008. Arbetsmarknad \& Arbetsliv 2009, 15, 2: 11-28, Karlstads Universitet.

Kjellberg, A. (2010a) Växande avgiftsskillnader i A-kassan-ökad social polarisering. Studies in Social Policy, Industrial Relations, Working Life and Mobility. Research Reports 2010: 2. Lund University, Department of Sociology.

Kjellberg, A. (2010b) Vilka "hoppade av" a-kassan eller avstod från att gå med? En studie av a-kassornas medlemsras. Research Reports 2010: 30. Lund University, Department of Sociology.

Kjellberg, A. (2011) The Decline in Swedish Union Density since 2007. Nordic Journal of Working Life Studies. 1, 1: 67-93.

Lind, J. (2007) A Nordic Saga: The Ghent System and Trade Unions. International Journal of Employment Studies 15, 1: 49-68.

Munch Haagensen, K. (ed.) (2011) Nordic Statistical Yearbook 2011. Nord 2011:001, vol. 49. Nordic Council of Ministers, Copenhagen.

Mýri, M. H. (2011) Løn og kynsbýtið á almenna arbeiðsmarknaðinum-ein perspektivering. Granskingardepilin fyri Samfelagsmenning, arbeiðsrit nr. 27/2011.

Schaapman, M. \& van het Kaar, R. (2007) Social Partners and Social Security Systems. Eurofond Publication. Ireland, Dublin.

Scruggs, L. (2002) The Ghent System and Union Membership in Europe, 1970-1996. Political Research Quarterly 55: 275. Sage, The University of Utah.

Statistics Faroe Islands: Hagstova Føroya (2011) Faroe Islands in figures 2011. Hagstova Føroya, Argir Faroe Islands.

The Confederation of Swedish Enterprise: Eriksson, M. \& Segerfeldt, F. (2011) Mångfald $i$ arbetslöshetsförsäkringen. Svenskt Näringsliv, Stockholm.

The Nordic Council of Ministers: TemaNord (2011:559) Ökat behov av nordisk samverkan $i$ en förändrlig omvärld. Nordiskt Arbetslöshetsförsäkringsmöte 2011. Nordiska ministerrådet.

The Confederation of Swedish Enterprise: Eriksson, M. \& Segerfeldt, F. (2011) Mångfald $i$ arbetslöshetsförsäkringen. Svenskt Näringsliv, Stockholm. 


\section{Electronic resources}

The Faroese unemployment system: ALS:1 Hvat er ALS-gialdið. http://www.als.fo/Default. aspx? pageid=3346 (2012-09-25).

The Faroese unemployment system: ALS:2 Hvussu nógv - og hvussu leingi? http://www.als. fo/Default.aspx? pageid=3264 (2012-04-11).

ALS 2003:Àlit um broytingar í Løgtingslóg um arbeiðsloysistrygging og arbeiðsávísing 2003. http://www.vmr.fo/Admin/Public/DWSDownload.aspx?File=\%2FFiles\%2FFiler\%2FVMR\%2F Fragreidingar\%2F\%26Aacute\%3Blit+fr\%26aacute\%3B+nevndini+080205.pdf (2012-04-11).

Parliamentary news: Løgtingstíðindi 1992, mál nr. 173: Uppskot til broyting í Løgtingslóg um arbeiðsloysistrygging og arbeiðsávísing, s. 864. http://logting.elektron.fo/lgt/prenta.asp? ar=1992\&fil=00060182.GIF (2012-10-08).

Parliamentary news: Løgtingstíðindi 1992, mál nr. 186: Uppskot til broyting í Løgtingslóg um arbeiðsloysistrygging og arbeiðsávísing, s. 973. http://logting.elektron.fo/lgt/prenta.asp? ar=1992\&fil=00060291.GIF (2012-04-11).

Parliamentary law: Samanskrivað løgtingslóg nr. 113 frá 13. juni 1997 um arbeiðsloysistrygging og arbeiðsávísing, sum broytt við løgtingslóg nr. 12 frá 9. februar 2001. http://www. als.fo/Default. aspx? pageid=3497 (2012-02-27).

Parliamentary law: Løgtingslóg nr.113 frá 13. juni 1997 um arbeiðsloysistrygging og arbeiðsávísing, sum seinast broytt við Løgtingslóg nr. 46 frá 17. mai 2011. http://www.logir.fo/ foldb/llofo/1997/0000113.htm (2012-02-27).

Parliamentary case: Løgtingsmál nr.139/2010: Uppskot til løgtingslóg um at broyta løgtinslóg um arbeiðsloysistrygging og arbeiðsávísing. Vmr. J.Nr.: 10/00711 Vinnumálaráði, Tinganes. http://www.logting.fo/casenormal/view.gebs? menuChanged=16\&type=0\&caseNorm al.id=1839 (2012-04-11).

Statistics Faroe Islands: Hagstova Føroya (2005:1) Nógv parttiðararbeiði, serliga millum konufólk. http://www.hagstova.fo/portal/page/portal/HAGSTOVAN/Hagstova_Foroya/news_ repos/ARB_FJOLDARKANNING_2005_PARTTIDARARB (2012-10-08).

Statistics Faroe Islands: Hagstova Føroya (2005:2) Flest arbeiðsvirkin i Føroyum í mun til fólkatalið. http://www.hagstova.fo/portal/page/portal/HAGSTOVAN/Hagstova_Foroya/news_repos/ ARB_FJOLDARKANNING_2005_ARBVIRKIN (2012-02-13).

Statistics Faroe Islands: Hagstova Føroya (2012) Arbeiði. http://www.hagstova.fo/portal/ page/portal/HAGSTOVAN/Hagstova_Foroya/tema/ARBEIDI (2012-02-13).

\section{End notes}

${ }^{1}$ The term Ghent system is a generic one for a voluntary unemployment scheme that is administered by a trade union even though it is partly state-subsidized. In the Nordic context, Sweden, Denmark, Finland, and Iceland have Ghent systems (Scruggs 2002).

${ }^{2}$ Prior to 1992, the Faroe Islands had no UBS at all (ALS 2003).

${ }^{3}$ I draw a distinction between the terms unemployment benefit and unemployment insurance since the former entails the individual's right to some sort of economic compensation while the latter pre-requires the active choice of taking out insurance. 
${ }^{4}$ Unfortunately these numbers have not been verified since statistics in this regard are very limited.

${ }^{5}$ As a consequence of the rising number of unemployed, this level was reduced to 17,500 per month DKK during the first quarter of 2012. 